\title{
The Nature and Function of Criminal Theory
}

\author{
George P. Fletcher*
}

\section{INTRODUCTION}

The practice of teaching and writing in the field of criminal law has changed dramatically in the last half-century. In the United States and England, and to a lesser extent in other English-speaking countries, we have witnessed a turn toward theoretical inquires of a greater depth and variety than had existed previously in the history of Anglo-American law. The subjects of this new literature include the nature and rationale of punishment; ${ }^{1}$ the theory of justification and of excuse, that is, of wrongdoing and responsibility; ${ }^{2}$ the relevance of consequences to the gravity of offenses (the problem of moral luck); ${ }^{3}$ and the proper structuring of specific fields of law, notably the law of homicide, particularly at the beginning and the end of life, ${ }^{4}$ of rape, ${ }^{5}$ and of victimless offenses that result in

Copyright $\odot 2000$ George P. Fletcher. The editors have been unable to verify the foreign sources contained in this Essay. The author is therefore entirely responsible for their accuracy.

* Cardozo Professor of Jurisprudence, Columbia University School of Law.

1. See H.L.A. Hart, Prolegomenon to the Principles of Punishment, in Punishment ANd Responsibility: Essays IN The Philosophy of LaW 1 (1968); Herbert Morris, Persons and Punishment, in ON GuIlt and INNocence: Essays IN Legal, PhIlosophy and Moral. Psychology 31 (1976).

2. See H.L.A. Hart, Legal Responsibility and Excuses, in PunIsHMENT AND Responsibility: Essays IN THE Philosophy of LAW, supra note 1, at 28; J,L. Austin, A Plea for Excuses, in 57 PROC. ARISTOTELIAN SOC'Y 1 (1957); George P. Fletcher, The Individualization of Excusing Conditions, 47 S. CAL. L. REv. 1269 (1974); George P. Fletcher, Proportionality and the Psychotic Aggressor: A Vignette in Comparative Criminal Theory, 8 IsRAEL L. REv. 367 (1973); Paul H. Robinson, A Theory of Justification: Societal Harm as a Prerequisite for Criminal Liability, 23 UCLA L. REv. 266 (1975).

3. See Model Penal Code $\S 5.05(1)$ (Proposed Official Draft 1962); Joel Feinberg, Doing AND Deserving. Essays IN THE Theory of Responsibility 33 (1970); H.L.A. Hart, Intention and Punishment, in Punishment and Responsibility: Essays In the Philosophy of Law, supra note 1, at 113, 129-131; Thomas Nagel, Moral Luck, in MoRTal Questions 24 (1979); Sanford H. Kadish, Foreword: The Criminal Law and the Luck of the Draw, 84 J. CRIM. L. \& CRIMINOLOGY 679 (1994); Stephen Schulhofer, Harm and Punishment: A Critique of Emphasis on the Results of Conduct in the Criminal Law, 122 U. PA. L. REv. 1497 (1974).

4. See Jonathan Glover, Causing Death and Saving Lives (1977); George P. Fletcher, Prolonging Life, 42 U. WASH. L. Rev. 999 (1966-1967); Sanford H. Kadish, Letting Patients Die: Legal and Moral Refiections, in IN HARM's WAY: EsSAYS IN HONOR OF JOEL FEINBERG 290 (1994); Sanford H. Kadish, Respect for Life and Regard for Rights in the Criminal Law, 64 CALIF. L. REV. 871 (1976); Judith Jarvis Thomson, A Defense of Abortion, 1 PHIL. \& PUB. AfF. 47 (1971). 
no material harm to other persons. ${ }^{6}$ As far as the United States goes, the roots of this flowering lie in the classic article by Jerome Michael and Herbert Wechsler, A Rationale of the Law of Homicide. ${ }^{7}$ The casebook by the same authors provided the first serious teaching tool for a reflective and systematic approach to American criminal law. ${ }^{8}$ The Model Penal Code, a project initiated by Herbert Wechsler and the American Law Institute in the 1950 s, brought together many of the most serious legal minds of the generation to work out, for the first time, the rules and principles that would constitute the general part of American criminal law, namely the rules and principles that would be applicable to all offenses. ${ }^{9}$ And significantly, the 1962 publication of the first edition of the novel, theoreticallyminded casebook by Sanford Kadish and Monrad Paulsen ${ }^{10}$ helped to create a community of scholars who read the same cases and followed up on the same set of citations to the journals and law reviews.

There were certainly historical precursors to this burst of theoretical inquiry. Stephen, ${ }^{11}$ Mill, ${ }^{12}$ Bentham, ${ }^{13}$ and Blackstone ${ }^{14}$ come readily to mind. One of the most famous maxims of the theoretical criminal lawactus not facit reus nisi mens sit rea ${ }^{15}$-dates back to Edward Coke's formulation in the early seventeenth century. ${ }^{16}$ Yet this earlier legal literature consists largely in apodictic statements about how the criminal law should be formulated. It lacks the reflective attention to issues that we have come to associate with philosophical mquiry.

In trying to understand the nature and function of this theoretical work, the term "philosophy" is the first descriptive word to come to mind.

5. See SuSAN Estrich, Real Rape (1987); E. M. Curley, Excusing Rape, 5 Phil. \& Pub. Aff. 325 (1976); Susan Estrich, Rape, 95 YALE L.J. 1087 (1986).

6. See Patrick Devlin, The Enforcement of Morals (1965); H.L.A. Hart, Law, Liberty AND MORALITY (1963); Sanford H. Kadish, More on Overcriminalization: A Reply to Professor Junker, 19 UCLA L. REv. 719 (1972); Sanford H. Kadish, The Crisis of Overcriminalization, 374 ANNAls AM. ACAD. Pol. \& Soc. SCI. 157 (1967).

7. Herbert Wechsler \& Jerome Michael, A Rationale of the Law of Homicide: I, 37 CoLum. L. Rev. 701 (1937) [hereinafter Wechsler \& Michael I]; Herbert Wechsler \& Jerome Michael, $A$ Rationale of the Law of Homicide: II, 37 CoLuM. L. REv. 1261 (1937) [hereinafter Wechsler \& Michael II].

8. See Jerome Michael \& Herbert Wechsler, Criminal Law and Its administration (1940).

9. See Model Penal Code (Proposed Official Draft, 1962).

10. See Monrad G. Paulsen \& Sanford H. Kadish, Crimnal Law and Its Processes (1962).

11. See James Fitzjames Stephen, A History of the Criminal Law of England (1883).

12. See John Stuart Mill, ON Liberty 22 (Gertrude Himmelfarb ed., Penguin Books 1985) (1859).

13. See Jeremy Bentham, An Introduction to the Principles of Morals and Legislation (J.L. Burns \& H.L.A. Hart ed., Clarendon Press 1996) (1823).

14. See William Blackstone, Commentaries on the LaW Of England (1765).

15. Literally translated: "The act is not criminal unless the mind is criminal."

16. See EdWARd CoKe, The Third PART of The Institutes of the Law of ENGland 107 (1644). 
Indeed, without the devoted interest of a group of philosophers in the 1950s and 1960s, it is doubtful that the field would have taken off. The philosophical analogue to Herbert Wechsler was H.L.A. Hart, who, as teacher and scholar, brought the methods of analytic philosophy to bear on the study of criminal law. Herbert Morris, ${ }^{17}$ Joel Feinberg, ${ }^{18}$ Robert Nozick, ${ }^{19}$ Judith Jarvis Thomson, ${ }^{20}$ and many others deepened this interdependency of law and philosophy. These philosophers were building on a long tradition dating back, on some issues, to Aquinas and even to Aristotle. Yet the major debates in the philosophical reflection on the criminal law have a distinctively modern ring to them. Established authorities have been punishing criminals from the beginning of organized society, but it is not until the late eighteenth century that we find serious engageinent and disagreement about the purposes of inflicting this harm on those who have transgressed the norms of the community. Today, we take the debate between Kant's retributivism and Bentham's utilitarianism to be paradigmatic of the style of intellectual confrontation that has induced philosophical reflection on every factor bearing on the question whether we should punnsh a particular individual on a particular occasion.

At this juncture, on this occasion honoring one of the founders of the field, it might be appropriate to pause and reflect on the nature and the function of this shared inquiry into the foundations of the substantive criminal law. Criminal theory has clearly come of age, and therefore it can endure this Essay, written as a critical assessment both of its promise and its shortcomings.

\section{I}

\section{What Kind of Inquiry Is CRIMINAL Theory?}

The field of criminal theory should be thought of more as a humanist inquiry than as a social science. The questions that concern us are not einpirical. The task is not to explain how the system actually works. Of course, it is important to know, for example, how the police function, how juries decide, how the system effects minorities, and so on. So far as other researchers can inform us of these facts of life, we should take note. This is not, however, the essence of the theoretical enterprise.

To say that the field is a humanist inquiry underscores the great mystery of the human condition that comes into focus in criminal trials. How is it that human beings can commit heinous acts, and low can we justify

17. See Morris, supra note 1.

18. See Feinberg, supra note 3; Joel Feingerg, The Moral Limits of the Criminal Law (1984) [hereinafter FeinberG, Moral Limits].

19. See Robert Nozick, ANarchy, State and Utopia (1974) [hereinafter Nozick, ANarchy]; Robert Nozick, PhILosophical Explanations (1981).

20. See Judith Jarvis Thomson, Rights, Restitution, and Risk: Essays in Moral Theory (William Parent ed., 1986). 
blaming and punishing them for having committed them? The first part of this question stresses the issues of individual guilt and punishment and connects readily to moral philosophy. The second part, regarding collective blaming and state punishment, raises a question of political philosophy: When should the state be able to act in the common good by imposing sanctions against particular individuals? As criminal theory lies at the union of law and philosophy, it also defines an intersection between moral and political philosophy.

These two points of intersection require further reflection. First, how do law and philosophy impose competing perspectives on theoretical work in criminal law? And second, how do moral and political philosophy differ in their concerns and procedures?

\section{A. The Differing Demands of Law and Philosophy}

Law and philosophy are in fact two entirely different kinds of inquiry, and the difference between thein is captured in the word "authority." Legal studies proceed by reflecting on the meaning and extension of certain authoritative texts-constitutions, statutes, regulations, and case holdings. This deference to authoritative rules and prescriptions runs contrary to the philosophical inethod, which involves searching for the best reasons to defend a particular position. Law tends toward the parochial, for authority is always limited to a particular time and place. If you are thinking about self-defense and the duty to retreat in the United States, you pay attention to American authorities. If you are thinking about self-defense in Germany, you heed the local statutory and case law and scholarly prescriptions about self-defense. By contrast, philosophy represents a universal inquiry independent of time and place. No one is constituted as the authority to prescribe certain sources as the ones you must read and think about. ${ }^{21}$ In doing legal theory, it is a mistake to ignore the local criminal code; but if you do not find Hegel illuminating, it is not a "mistake" in a philosophical inquiry simply to ignore him.

Admittedly, in the Umited States, we enjoy a certain tendency toward universalist thinking that is not shared by our colleagues in Germany, France, and Italy. If you live and teach in California, you are not limited in your horizons to the California Criminal Code and the California cases. Indeed, these naterials have no privileged position in any of the great casebooks, such as the book by Kadish and Paulsen, now transfornied into Kadish and Schulhofer ${ }^{22}$ Cases froin New Zealand are just as important as those from the court down the street, and Stephen's draft code for India

21. For more in this vein, see George P. Fletcher, What Law is Like, 50 SMU L. Rev. 1599 (1997).

22. See Sanford H. Kadish \& Stephen J. Schulhofer, Criminal Law and its Processes (6th ed. 1995). 
carries weight, as does the Model Penal Code. The degree of parochial thinking outside the English-speaking world is much stronger. French writing on criminal law reveals little knowledge about legal sources outside of France, and the Germans, who know more about law abroad, still write and teach as though the authoritative German materials define their universe of inquiry.

In the end, however, the difference between the English-speaking world, or "common law system," and the rest of the world is simply a inatter of degree. A large number of Anglophone countries share the same language and take cognizance of each others' legal sources, but the boundaries of parochial thinking become clear sooner or later. Englishspeaking lawyers do not recognize the relevance of legal authorities written in other languages. They might be curious about odd things done in one country or another, but they do not take "foreign" statutes or cases seriously as authorities that constrain their thinking.

This parochial thinking runs afoul of the philosophical temper. There is nothing about philosophy written in English that makes it intrinsically more appealing than works originally published in Greek, Latin, or German. Indeed, it is not clear why in philosophical inquiries one cares at all about what philosophers in the past have said. Philosophy is not the history of philosophy, as my teacher Norman Malcolm used to preach. Yet teachers of philosophy do in fact concentrate on reading and explicating the "greats" as though their work commanded some authority on the problems they raise. Perhaps there is a need to start somewhere, and those who have brought wisdom to bear in the past warrant the honor of having the first, if not necessarily the last, word in the discussion.

The danger in legal studies is to treat jurists of the past, who were often rather pedestrian thinkers, as having the last word in determining what the law is. We read their constitutions, statutes, and case opinions as though they actually solved the problem they were addressing. We do this for various reasons. Their words acquire authority by virtue of the political system that we are willing to live by or, in the case of constitutions, because they lived and wrote at particularly poignant moments in history, such as the concluding hours of a political revolution.

One is tempted to draw an analogy between the reliance of lawyers on their parochial sources of law and the invocation of God's recorded word in a religious community. The culture of the law is, in fact, much like the culture of religious belief. Both start with the text. But a sophisticated practitioner of either law or religion will always seek to go beyond the text and bring to bear the insights of reason on the ultimate issues at hand. Theology, when it is done well, resembles the informed groping of legal theorists trying to bring diverse sources to bear on the ineffable problems of action, responsibility, guilt, and justified punishment. Great religious 
thinkers like Maimonides and Aquinas never limited themselves to the sources of revelation. Great legal minds proceed in a similar way: They take their traditions seriously (the analogue to revelation) and move beyond them in the direction of universal answers based on the kinds of reasoning that could appeal to thinking people everywhere.

The appeal of the analogy between theology and legal thought is that it accounts for the parochial nature of legal studies. The loyalty that lawyers show to their local constitutions, statutes, and cases is quite remarkable and can only be understood as the expression of a culture of faith. At some level Americans must believe that those fifty-five white men who met in Philadelphia in the sweltering summer of 1787 really got it right. At least they believe it in a way that Europeans and Chinese hardly share. These commitments to belief resemble the socialized instincts of members of religious communities. They take their own holy texts seriously and totally ignore, if not attack, the texts of neighboring cultures.

Scholars who seek to work on the philosophical foundations of criminal responsibility, then, are caught between the forces of competing disciplines. The customs of legal scholarship drive theorists toward taking the indigenous "sources of law" seriously, treating them as the authoritative basis for solving problems. The traditions of philosophy generate an inpulse toward universalist arguments based on sources available to all. This conflict comes to the fore in assessing the relevance of particular decisions by the courts or legislatures. Suppose that the local law givers have decided that strict liability is acceptable in rape cases, that consequences inatter in assessing the gravity of punishment, that felony-murder is a permissible doctrine, or that the insanity defense is indispensable in a proper assessment of criminal responsibility. Why should the theorist care about these purely parochial decisions? Of course, they should matter if the theorist has sound reasons for thinking that the decisions are right. But the fact that some judge somewhere made a certain decision hardly generates a sound reason in itself for taking the decision to be authoritative.

The problem becoines more difficult if we can detect a pattern of decisions and principles that cuts across legal systems and constitutes a nearly universal practice. A good example is the relevance of consequences to determining the gravity of an offense and the severity of punishment. Virtually all legal systems in the world punish completed offenses more severely than they punish attempts. Harm inatters-at least in the way the vast majority of lawyers and judges think about things. Yet a considerable body of theory has developed to the effect that under a proper analysis of culpability, consequences should be regarded as purely arbitrary and therefore irrelevant to the actor's criminal responsibility. ${ }^{23}$ An actor, malicious to his core, may shoot to kill, but for purely physical

23. See, e.g., sources cited supra note 3. 
reasons the bullet may not strike home. The argument is that this blameworthy actor is just as culpable as one who succeeds in his intentions. This argument is sufficient to turn some distinguished minds, including Joel Feinberg and Sandy Kadish, to the view that last-step attempts (where there is nothing more the actor can do) should be punished just as severely as actions that actually succeed and result in irreversible harm. ${ }^{24}$

Here is an example of practice in conflict with theory, and the question is how to proceed. Is there a rule of thumb telling us whether to favor theory over practice? Alas, no. It all depends on the practice and on the theory. In this particular case, I happen to think the theoretical arguments are wrongly conceived and developed (as I will show later), and the practice should constitute the basis of our philosophical inquiry. The question should not be whether the nearly universal practice is right, but why it is right. Here I rely on a point of philosophical psychology that I learned from my mentor Herbert Morris: When an intuition is deeply held, the task of theory should be to generate convincing arguments that those who hold the intuition may not be able to articulate themselves.

The problem with this view is that some widespread practices are clearly wrong, or at least inconsistent with other basic principles of the criminal law. Perhaps there are many people who would claim that the felony-murder rule represents a deeply held intuition. Yet the general theory of culpability holds that actors should be held responsible for the consequences of their actions only to the extent that they are culpable in generating those consequences. Culpability is determined by considerations such as whether the actor intended the consequences; whether she acted knowingly, recklessly, or negligently with respect to the risk of the consequence; and whether she is excused or partially excused for her actions. An offender who accidentally kills someone in the course of a robbery is not, without further proof, culpable for the homicide. Yet the felony-murder rule in effect presumes culpability with respect to the result, in violation both of the requirement of culpability and the presumption of innocence. Again, there is conflict between practice and theory. Should the theorist apply the Morris maxim and seek to defend the felony-murder rule as a deeply held intuition of common people, just like the judgment about the relevance of consequences to punishment?

My answer is: clearly not. But now we face a serious problem of methodology. How do we decide when to take the practices of the legal system seriously and when not? Here are a few suggestions about how to proceed in thinking through this matter.

First we have to clarify whose intuitions we are talking about. Do we mean the intuitions of the man, woman, and child on the street? Do we

24. See FeINBERG, supra note 3; Kadish, supra note 3. 
follow the results of the interesting study by Robinson and Darby ${ }^{25}$ on the intuitions of common people about the conundrums of the type we have been discussing? Or do we mean the educated intuitions of lawyers and judges-people trained and perhaps "corrupted" by the criteria of legal analysis? I would not be at all surprised if the guy in the street were to favor both (a) treating consequences as irrelevant to the punishment of the person who acted with evil intent and (b) blaming the robber for the homicide that his criminal action accidentally brings about. But so what? A refinement of our intuitions takes place when we work on the casuistic problems of legal analysis. It seems to be more sensible to rely upon the intuitions of actors in the actor culture. But then comes the response: They, like the guy in the street, seem to favor the felony-murder rule.

At this juncture in the argument, comparative law becomes acutely relevant. If a practice is widespread among legal systems, there is good reason to think that it reflects an intuition that we should credit and seek to justify. If, on the other hand, the United States is isolated in its practice, we should have second thoughts about taking our local and parochial judgments seriously. In the case of the felony-murder rule, it is difficult to find a jurisdiction outside the United States-even in the English-speaking world-that still applies the rule. Also relevant, it seems to me, is the strength of the opposition to the parochial position of the United States. The Canadian Supreme Court has declared various aspects of the felonymurder rule unconstitutional. ${ }^{26}$ One could expect a similar decision in Germany and Italy; if they had the rule, their courts would probably find it to be in violation of their constitutional requirement of culpability as a condition for criminal responsibility. ${ }^{27}$

Of course, American politicians and policy makers are notoriously indifferent to the attitudes of jurists beyond our borders. Witness our persistent faith in capital punishment despite the dehberate killing of offenders having been discredited every other place in the civilized world. But politicians' parochial attitudes provide no excuse for scholars of criminal theory to remain indifferent to the patterns that have emerged in Western jurisprudence. Our perspective should reach wider than our language and deeper than our supposedly shared debt to the English common law.

I am not arguing that the theorist should submit to every worldwide trend. Sometimes trends are wrong. A good example, in my opinion, is the widespread tendency toward punishing impossible attempts, a trend that has become manifest in the last few decades in England, the United States,

25. See Paul H. Robinson \& John M. Darley, Justice, Liability and Blame: Community Views and the Criminal LaW (1997).

26. See R. v. Martineau [1990] 2 S.C.R. 633.

27. See Günther Jakobs, Strafrecht Allgemeiner Teil $470-75$ (2d ed. 1993); 1 Claus Roxin, STrafrecht Allgemeiner Teil § 19 (3d ed. 1997); Corte cost., 23-24 mar. 1988, available in 31 Revista Italiana di Diritto e Procedura Penale 686 (1988). 
and Germany. The argument is that if the actor intends to commit a crime and engages in a serious effort to execute his intention, there is no reason to give him the benefit of the circumstances turning out to be different from what he expected. Yet there are also counterindications in the legal thought of the industrialized world. Japan and Italy have always held out against the intent-based, subjective theory. ${ }^{28}$ Spain has recently joined the ranks of European countries favoring the countertrend. ${ }^{29}$ When the nations of the world are so clearly divided, we have to probe the arguments for and against more deeply. The trend means very little if it is not in keeping with the best arguments available for and against criminal liability.

The problem is: How do we evaluate the arguments bearing on criminal responsibility? If we have a conflict between theory and practice, we should be very sure that our theoretical or philosophical arguments are well-grounded. If the arguments invoke the "authority" of Kant or Aristotle, then we should be sure that we have read these supposed authorities correctly. My favorite example of philosophical misreading is the attempt to invoke Kant's theory of the goodwill in morality to support a concentrated focus on criminal intention as the basis of criminal liability. Kant argued that a goodwill-as he understood that term-was essential to the claim that an act had moral value. ${ }^{30} \mathrm{He}$ never argued that a bad will rendered an action evil. Yet we find recurrent efforts in criminal theory to adapt Kant's thinking to support, for example, the view that consequences should not matter im assessing the gravity of the offense. ${ }^{31}$ The argumentto the extent that it can be articulated-would run as follows:
A: A goodwill is necessary for an action to be good.
B: A goodwill implies a good intention. Therefore a good imtention renders an action good.
C: A bad will implies a bad intention and a bad intention renders an action evil.
D: If the intention is sufficient to make an act good or evil, then the consequences are irrelevant to determining the good or evil represented by the action.

If these imferences, from $\mathrm{A}$ to $\mathrm{B}, \mathrm{B}$ to $\mathrm{C}$, and $\mathrm{C}$ to $\mathrm{D}$, were correct, Kantian theory might provide some support for the view that the core of the criminal law consists in evil intentions and that consequences should be

28. See Codice Penale [C.P.] § 49(2) (Italy); see also Shigemitsu Dando, The Criminal LAW of Japan 202-08 (B.J. George trans., 1997); Giovanni Fiandaca \& Enzo Musco, Diritto Penale: Parte Generale 430-31 (3d ed. 1995).

29. See Código Penal [C.P.] § 16(1) (Spain) (defining attempt to require action that "objetivamente deberian producir el resultado" [that would objectively produce the result]).

30. See Immanuel Kant, Fundamental Principles of the Metaphysic of Morals 17-18 (Thomas K. Abbott trans., 1949).

31. See, e.g., Michael S. Moore, The Independent Moral Significance of Wrongdoing, $5 \mathrm{~J}$. Contemp. Legal Issues 237, 240 (1994); A.W. Moore, A Kantian View of Moral Luck, 65 PHIL. 297, 304 (1990). 
irrelevant to assessing just punishment. But apart from the first premise, all of these inferences are false. Here is a short explanation why:

A: This represents a correct reading of Kant's view as set out in the first few lines of The Prolegomenon to the Metaphysics of Morals. ${ }^{32}$

A to B: In the Kantian system, intention differs fundamentally from will. Der Wille is defined as the capacity to act without the influence of sensual stimuli from the external world; it is the capacity to reflect the dictates of the universal law of reason. ${ }^{33}$ That is why an act can have a moral quality only if it is an expression of der Wille. It is not true that a good intention, which might be responsive to sensual stimuli in the world, renders an action good. There is no reason to think that an intentional act, just because it is intentional, is a product of der Wille.

$\mathrm{B}$ to $\mathrm{C}$ : This is probably the biggest fallacy of the set. Under the Kantian system, good acts and bad acts are asymmetrical; if a theory applies to the former, it does not necessarily apply to the latter. For an act to have moral worth it must be autonomous. Bad acts are, by definition, heteronomous. ${ }^{34}$ They are not products of der Wille. One cannot autonomously choose to do evil, to commit a crime. Of course, under Kant's legal theory, we find a lengthy discussion of crime and punishment. ${ }^{35}$ But Kant explicitly describes the seat of criminal conduct as die Willkür (heteronomous arbitrary choice) rather than der Wille (autonomous choice based on reason). ${ }^{36}$

C to D: In his extensive discussion of criminal actions, Kant ignores the problem of attempts and inchoate acts. All the examples given are those based on consummated actions. The conclusion that consequences are foreign to the Kantian way of thinking about crime and punishment represents a total perversion of Kantian thought.

Despite all of these errors, this misreading of Kant has won the loyalty of some sophisticated thinkers. ${ }^{37}$ It is one of the primary props of the supposedly theoretical argument in favor of punishing attempted offenses at the same level as consummated offenses. Perhaps lawyers are naturally drawn to the citation of philosophical authority; it is a professional vice.

32. KANT, supra note 30 , at 11.

33. See ImManuel Kant, Foundations of the Metaphysics of Morals 11 (Lewis White Beck trans., 1959) (1785); see also George P. Fletcher, Law and Morality: A Kantian Perspective, 87 Colum. L. Rev. 533 (1987).

34. See id. at 537.

35. See Immanuel Kant, The Metaphysical Elements of Justice (John Ladd trans., 1985).

36. For a critical assessment of my views on der Wille and die Willkïr, see Peter Benson, External Freedom According to Kant, 87 CoLum. L. Rev. 559, 561-62 (1987).

37. See, e.g., Charles Fried, Right ANd Wrong 48 (1978); Joshua Dressler, New Thoughts About the Concept of Justification in the Criminal Law: A Critique of Fletcher's Thinking and Rethinking, 32 UCLA L. REv. 61, 80 (1984). 
But if the name of one of the great philosophers of modernity comes into play, one should at least get the reading right.

Writers of legal theory are drawn not only to Kant but to Aristotle. The Nichomachean Ethics is often cited to support analysis of the theory of excuses. ${ }^{38}$ I think that, by and large, this tracing of excuses to Aristotle is correct, even though the philosopher was concerned not about criminal responsibility but about the problem of virtue and the flourishing of individuals. Though Aristotle has many insights to offer, we should be careful about relying on an exegesis of his text to decide, for example, whether negligence is a suitable ground for criminal liability. That was not a problem to which he addressed his energy.

Apart from relying on these historical "authorities," theorists are left with few convincing arguments in their arsenal. Michael Moore relies heavily on imtuition, ${ }^{39}$ but, as we have noted, we have a serious problem determining whose intuitions should matter and why. Strict logical arguments are rare in the literature. Recently Russell Christopher has pressed the avoidance of contradiction as an argument for structuring the theory of justification, ${ }^{40}$ and his work may portend an effort to develop more rigorous arguments for particular outcomes in the theory of criminal responsibility.

As things stand now, our methods of argument are a hodgepodge of intuition, citations to case law, philosophical references (sometimes laced with misreading), and, of course, policy arguments about the behavior we seek to encourage and discourage. There has been and presumably always will be attention paid to the classic debate between retribution and deterrence as the rationale for punishment and, in general, between deontological and utilitarian approaches to moral problems. Yet there has not been enough attention paid to the difference between moral, political, and other kinds of arguments about the proper approach to criminal law.

\section{B. The Differing Perspectives of Political and Moral Philosophy}

Criminal law begins with punishment, and the kind of punishment with which we are concerned represents an intrusion of the state into the individuals' freedom. Therefore the first question that 1nust be asked is all

38. See Michael Corrado, Automatism and the Theory of Action, 39 EMORY L.J. 1191 (1990); John Gardner, The Gist of Excuses, 1 BuFF. CRIM. L. REV. 575 (1998); Kyron Huigens, Virtue and Inculpation, 108 HARV. L. REv. 1423 (1995).

39. See Michael Moore, Placing Blame: A General Theory of the Criminal law (1997).

40. See Russell Christopher, Self-Defense and Defense of Others, 27 PHIL. \& PuB. AFF. 123 (1998); Russell Christopher, Self-Defense and Objectivity: A Reply to Judith Jarvis Thomson, 1 BuFF. CRIM. L. REv. 537 (1998); Russell Christopher, Unknowing Justification and the Logical Necessity of the Dadson Principle in Private Defence, 15 OxF. J. Leg. STud. 229 (1995); Russell L. Christopher, Mistake of Fact in the Objective Theory of Justification: Do Two Rights Make Two Wrongs Make Two Rights . . ? , 85 J. CRIM. L. \& CRIMINOLOGY 295 (1994). 
too often ignored: What makes it legitimate for the state to make people suffer? The answer can hardly be, "The state must do justice," or "Criminals deserve punishment." The preliminary demand is to develop a theory of the state that legitimates action in pursuit of justice or authorizes state agents to decide what people deserve and to distribute suffering accordingly. The range of these theories includes libertarian, liberal, commumitarian, utilitarian, and perfectionist theories of the state.

Given the centrality of political legitimacy in the criminal law, one can only be amazed at the extent to which the question is ignored both in the philosophical and legal literature. In Joel Feinberg's masterful study of the limits of the criminal law, ${ }^{41}$ there is almost no attention paid to political theory. Our leading liberal philosophers-Rawls, ${ }^{42}$ Dworkin, ${ }^{43}$ Ackerman ${ }^{44}$-have almost nothing of value to add to our understanding of criminal law. Libertarians such as Nozick do address the problem of legitimating state action, and indeed punishment is one of their central concerns..$^{45}$ Communitarians in the former Soviet Union also had a distinctive take on the phenomenon of crime and the role of the state in educating "the new person" who would transcend the corruption of bourgeois society. ${ }^{46}$ But apart from the libertarians and the Communists at the extremes, the vast majority of us are simply unreflective liberals. We are suspicious of common law crimes and accept at face value Mill's principle that the state should punish only to prevent harm, ${ }^{47}$ and we take these two positions to be an adequate theoretical foundation for our work.

Perhaps the greatest theoretical tension in the literature derives from the simultaneous sympathy for certain liberal maxims and a commitment to retributive punishment. Liberals are supposed to believe that it is not the business of the state to try to formulate and act upon ultimate principles of justice; the state cannot purport to do God's work on earth. If that is true, it is hard to understand how the state can hold to a liberal epistemology and yet seek to right the "natural order" by punishing those who deserve it. Despite the great attention devoted to "desert" and retributive theory in recent years, no one has advanced a systematic argument about the political presuppositions of the state legitimately punishing offenders in the name of ultimate principles of justice. This, of course, has become a major problem in the international arena as well, for retributive impulses to

41. See Feinderg, Moral Limits, supra note 18.

42. See JoHn RAWLS, A THEORY OF JUSTICE (1971).

43. See Ronald DWORKIN, Law's EMPIRE (1986).

44. See Bruce A. Ackerman, Social Justice in the Liberal State (1980).

45. See NozicK, ANARCHY, supra note 19 , at 106-07, 135, 137-40.

46. The movement to educate a new person suitable for life under socialism made the Soviets particularly hostile to the theory of excuses. See generally HAROLD J. BERMAN, JUSTICE IN THE U.S.S.R. (1963).

47. See MiLL, supra note 12. 
punish war crimes and crimes against humanity-sometimes dressed up as an imaginary preventive policy-drive the formation of the new International Criminal Court. ${ }^{48}$ I think it is fine for the international commumity to believe that it must pumsh in the name of justice, but at least we should have some argument about how a diverse community of nations can claim to know what justice requires, and why it is empowered to prosecute and pumsh those who "deserve" punishment.

As far as domestic policies are concerned, the formerly fascist powers of Europe-namely Germany, Spain, and Italy-seem to be more sensitive than are we Americans to the demands of liberal or libertarian theory in practice. Perhaps a society must have had some experience with political corruption of the criminal law in order to develop strong liberal sensitivities. The battle against fascistic criminal law has led to certain liberal slogans designed to limit the power of the state over the lives of individuals. It is worth paying attention to two of these.

\section{Criminal Punishment Should Be Imposed for Acts Committed, Not for Being a Certain Kind of Person.}

This proposition is now taken for granted in most Western legal systems. It is expressed in the U.S. Supreme Court's aversion to status offenses. ${ }^{49}$ The German literature has cultivated the point as the distinction between an act-based criminal law (Tatstrafrecht) and an actor-based criminal law (Täterstrafrecht). ${ }^{50}$ Communitarian criminal law, taken to extremes in fascist and communist legal systems, has tended to focus on the whole person, on characteristics of social dangerousness, and on using the criminal sanction as a medium of social reeducation. Liberal regimes stress the limited focus of the criminal sanction; it must be imposed solely for acts, not for the crime of being different. It is worth noting that this limitation differs radically from some moral perspectives, particularly from an Aristotelian concern with virtue. Virtue theory focuses on character as it develops over time. Individual acts are important only so far as they reveal character and tend to develop a better or worse character in the future. We praise and condemn people for the kinds of character they have developed, but this perspective is not compatible with the deliberate limitation of criminal punishment to the condemnation of actions.

If American theories were more sensitive to the political dangers of an actor-based criminal law, we would be quick to criticize arguments based on the supposed dangerousness of certain types of offenders. We would

48. See Rome Statute of the International Criminal Court, Preamble, in 37 INT. LEGAL MAterials 999 (1998).

49. See Robinson v. California, 370 U.S. 660 (I962).

50. See Theodor Lenckner, Commentary, in ADOLF SchöNKE \& Horst SchrödER, STRAFGESETZBUCH: KOMMENTAR § I3 preliminary remarks, at 173-74 (25th ed. I997). 
have more trouble with increasing punishment for recidivists (and certainly with the policy of "three strikes and you're out") and with punishing impossible attempts on the ground that the mistaken actor is dangerous and likely to succeed next time. Yet it is very clear that American criminal theorists today are willing to accept certain actor-based arguments such as dangerousness inferred from past actions. ${ }^{51}$ And despite their lip service to liberal principles, German scholars have virtually no qualms about imposing liability for impossible attempts. ${ }^{52}$ This is fairly good proof that criminal theory seems to function today as a potpourri of political theory. Everyone seems to pick and choose from liberal, communitarian, utilitarian, and perfectionist assumptions as the choice suits their immediate purposes. But the task of the theorist should ideally be first to work out a political theory and then explore the implications of that political theory in the details of the criminal law.

\section{The Criminal Law Should Serve as the Last Resort (Ultimo Ratio). It Should Be Invoked Only if All Other Sanctions Fail.}

This additional principle for restricting the power of the state flies in the face of those, like Moore, who take retributivism so seriously that they think that the state has an absolute duty to punish all those who deserve it. ${ }^{53}$ A more restrictive theory of legitimate punishment would hold that the state must first seek to solve the problem of apparent crime by invoking less drastic remedies. For environmental offenses, corporate crime, embezzlement, and crimes of negligence, it might be sufficient to rely on the very effective American tort system. The fact that conduct is harmful and morally wrong hardly suffices to conclude that it must be treated as a punishable wrong under the criminal law. Tort liability, fueled by eager, contingency-fee-motivated private lawyers, might do the job just fine. However one comes out on this question, we cannot but recognize the issue at stake, namely: What is the general theory of the state, and how should it be applied to solve social problems?

My plea, then, is for criminal theorists to pay more attention to political as well as moral philosophy. The political theory we choose will invariably shape our answers to innumerable questions about what should be punished, when nominal violations are justified, and when wrongdoing should be excused.

51. See, e.g., Wechsler \& Michael $I$, supra note 7, at 757; Wechsler \& Michael $I I$, supra note 7, at 1272 .

52. See Strafgetsetzbuch [StGB] $§ 22$ (F.R.G.). This legislated acceptance of the subjective theory of attempts find general endorsement in the literature. See, e.g., Albin Eser, Commentary, in

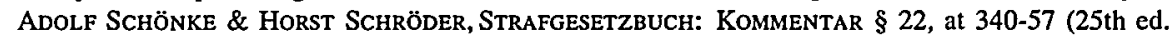
1997).

53. See MOORE, supra note 39, at 154. 
II

What Is the Function of Criminal Theory?

Much of the work done in criminal theory is really not about issues that could be classified as philosophical in the traditional sense. The function of much "theoretical" work in law is to probe the basic concepts that bear on legal analysis, order these concepts im some kind of structure, and elaborate the values and principles that lie behind the structure of hability. That is, the theorist takes the details of the criminal law as more or less given and tries to elicit from these details some synthetic principles. Consider, for example, the famous maxim formulated by Lord Coke in the early seventeenth century: Actus not facit reus nisi mens sit rea. ${ }^{54}$ Literally, this means that "the act is not criminal unless the mind is criminal." This is not a philosophical truth based on reason, but rather a synthetic claim about the criminal law as Coke observed it in practice. Every punishable act requires a union of actus reus and mens rea. Coke inferred the generality of his thesis from two primary cases. The first was the exemption provided in cases of theft for someone who acquired possession of an object and then decided later to keep it. Since the act was innocent at the time of acquisition, the subsequent criminal intent was insufficient to generate liability. ${ }^{55}$ The second case was the excuse recognized in cases of insanity. If the mind was not culpable, then the act could not be criminally culpable. ${ }^{56} \ln$ these two different applications of the principles of actus reus and mens rea, the terms mean different things, but I will not allow that point to detain us here. The fact is that Coke coined a maxim that, however ambiguous, has become a recognized truth about the criminal law..$^{57}$

As an accepted truth, Coke's maxim definitely functions as a constituent element of the law and as a source for further legal development. It has as much authoritative status as any legislative declaration or case holding. The courts will interpret legislative prescriptions in line with Coke's nraxim. They will seek to bring the details of the law into "reflective equilibrium" with this general maxim of the criminal law.

There are other maxims that express the same kind of synthetic truths of criminal justice. Consider these ten:

1. Every criminal offense presupposes a voluntary human act.

2. Every criminal offense imcludes a dimiension of wrongdoing.

3. Claims of justification negate wrongdoing.

4. Every punishable act presupposes blameworthy commission of the elements of the offense.

54. See discussion supra notes 15-16 and accompanying text.

55. See CokE, supra note 16 , at 107 .

56. See id. at 54.

57. This point is further explained in George P. Fletcher, Rethinking Criminal Law 27 n.59 (1978). 
5. Blameworthy commission requires at least negligent conduct with respect to every element of the offense.

6. Intentional, knowing, and reckless actions are worse than negligent conduct with respect to the elements of the offense.

7. Excused conduct is not blameworthy.

8. Reasonable mistakes are not blameworthy.

9. Subjective perceptions alone cannot justify conduct.

10. Self-defense is available only against unjustified attacks.

These are propositions that practitioners of criminal theory would, in varying degrees, hold to be true and binding as principle, at least to the same extent that Coke's maxim is binding on the criminal law. But few of them have ever been enacted by a legislature or written into a constitution, and most of them have never been clearly articulated in the Anglo-American case law. Nonetheless, they are just as binding as any principles implicit in our legal practices.

These ten propositions are grounded in the criminal law as it is routinely applied in most Western legal systems. And to the extent that they are grounded in the conventional behavior of the courts, their existence runs against the purely philosophical mode of inquiry I considered in the first half of this Essay. The authority for the principle is not reason alone, but reason as recognized in the practices of the community. The binding force of the propositions derives from the simple recognition by actors in the legal culture that we have felt bound by the underlying principle all along, whether we have articulated it or not.

By stressing the function of criminal theory as a source of binding principle, we have come to a more refined understanding of the nature of the discipline and the kind of philosophical work that enriches the effort. The starting point should not be the writings of the great philosophers but rather the humble, not-fully-understood work of lawyers, legislators, and courts. From the mundane we can derive deeper truths about the principles that drive the practice of punishing crime.

Yet the mundane is not enough. Neither Coke's maxim nor any of the ten principles that I have proposed find validation just in the language or decisions of the cases. The raw words and actions of practice require interpretation, and the interpretative framework must rest on a justification in political theory. Coke's maxim requiring the concurrence of actus reus and mens rea would hardly make sense if it did not stand for an important principle of legality. Yet it is not so clear why legality requires the temporal union of action and intent. What would be lost, say, by defining theft to permit a taking at one moment of time and the relevant intent at a later time? The answer is not obvious. Explaining the principle of concurrence requires that we ponder the foundations of the state's authority to punish and the nature of criminal responsibility. 
Once principles are adequately grounded, they acquire normative force in our analysis of criminal liability. They become a source of law. But what precisely does this mean? Suppose the legislated law deviates from a principle in a particular case? Is the principle refuted? If they were purely synthetic or empirical propositions, of course, an empirical counterexample would count against their continuing validity. But their appeal and their binding force are a function both of the extent to which they are realized in practice and of their intrinsic moral and logical appeal. I recognize that some of these propositions are controversial, and though I hold all of them to be true, many contrary voices sound in the Anglo-American literature.

These principles differ from the kinds of principles that Dworkin analyzed in his classic essay, The Model of Rules. ${ }^{58}$ These have not come into the law as conventionally recogmized ethical maxims - like the fanous "no one should profit from his own wrong." They derive rather, as did Coke's maxim, from theoretical reflection and generalization from the concrete instantiations of the principle.

Americans are loath to recognize that theoretical work of this sortcharacteristically the work of scholars and not of courts-generates maxims that have a binding effect upon the law. Europeans and Asiansparticularly those in the German sphere of influence-recognize that "theory" or scholarly generalizations of principle can provide a source of law along with legislation and case law. In these systems, theoretical commentary is not a secondary but a primary source of law.

Americans fail to grasp the dynamic of the so-called civil law because they fail to understand the significance of theoretical work as a source of law. As I have attempted to show in this Essay, we also fail to understand the way our own system of criminal law works because we have yet to appreciate the important role of theoretical generalization as a source of American law.

58. Ronald M. Dworkin, The Model of Rules, 35U. CHI. L. REv. 14 (1967). 
